\title{
Развитие орфографической зоркости младших школьников на уроках русского языка
}

\author{
Русский язык и литература
}

\section{Гагина А.B.}

учитель начальных классов МАОУ «Лицей №6»,г. Уфа

Важнейшим направлением обучения русскому языку в начальной школе является формирование у младших школьников грамотного письма, то есть письма, соответствующего нормам современного правописания. В ФГОС второго поколения по русскому языку главная роль отводится орфографической грамотности. «Грамотное письмо - это не просто движение пишущей руки, а особая речевая деятельность. Чем развитее ребенок, чем богаче его словарь и синтаксис, чем правильнее его произношение, тем легче дается ему правописание» - писал Н.С. Рождественский [2].

Проблема формирования орфографического навыка в начальной школе является одной из наиболее трудных задач.

Одной из причин недостаточно высокой орфографической грамотности младших школьников является несформированность их орфографической зоркости, т.е. неумение “видеть” орфограммы.

Актуальность этой темы заключается в том, чтобы сформировать азы орфографической грамотности на начальном этапе обучения, так как здесь закладываются основы грамотности, от которой зависит дальнейшее успешное обучение другим предметам.

Письмо - это вид речи, с помощью которого человек выражает свои мысли. В устной речи точности высказывания способствуют интонация, паузы, мимика. В письменной речи решению этой задачи способствует орфография. 
Цель исследования: теоретически обосновать и описать упражнения, направленные на формирование орфографической зоркости младших школьников.

Объектом исследования: является процесс обучения русскому языку младших школьников, направленный на повышение орфографической грамотности.

Предметом исследования: являются методические приемы обучения орфографии русского языка.

Очень важно научить обучающихся высокой культуре речи и письма, и в первую очередь, грамотного письма. Никому не секрет, что очень много обучающихся, знающих правила, но не умеющих писать без ошибок. Интуитивно пишущих - очень мало. Поэтому необходима специальная тренировка обучающихся, выработка у них орфографической зоркости, постоянная работа, направленная на предупреждение ошибок.

Орфографическая зоркость - это способность обнаруживать в словах, предназначенных для записи, орфограммы, а также определять их типы. Любого орфографического навыка можно достичь только при помощи упражнений, поэтому на уроке необходимо как можно больше писать.

Развитие орфографической зоркости следует начинать с первого класса. В основе грамотного письма лежит аналитико-синтетическая работа над слогом и словом, развитие фонематического слуха и умение заменить фонемы соответствующими буквами. Это задачи уроков обучения грамоте.

Задания, способствующие развитию пропедевтической работе, в период обучения грамоте:

«Поставь ударение!» Учитель называет слова с ударением на разных слогах (парта, корова, дерево, утро, воробей)

«Измени ударение!» На доске записаны слова: замок, полки, кружки, стрелки, хлопок.

Нужно изменить место ударения так, чтобы получилось другое слово и объяснить смысл данного слова. 
Профессор М.Р. Львов выделяет шесть этапов, которые должен пройти обучающийся для решения орфографической задачи:

1.Увидеть орфограмму в слове.

2.Определить вид: проверяемая или нет; если да, к какой теме относится, вспомнить правило.

3.Определить способ решения задачи в зависимости от типа (вида) орфограммы.

4.Составить алгоритм решения задачи.

5.Выполнить намеченную последовательность действий по алгоритму.

6.Написать слова в соответствии с решением задачи и сделать проверку [1].

В более обобщенном виде эти этапы представляются так: в орфографическом действии выделяются две ступени:

- постановка орфографической задачи, то есть найти орфограмму, определить тип;

- решение орфографической задачи - выбор способа проверки, установление последовательности проверки, применение правила к конкретному случаю и написание буквы-орфограммы [4].

Покажу на примере этапы действия обучающегося при определении орфограмм в слове натропи́нке - [натрап'инк'и]: - первая орфограмма раздельное написание предлога на (на лесной тропинке, на узкой тропинке), значит, предлог со словом пишется раздельно.

- вторая орфограмма находится в корне слова в слабой позиции, ребенок подбирает однокоренные слова тро́пы, тро́пка, где нужный гласный в сильной позиции, обозначает звук в слабой позиции той же буквой, что и под ударением; - следующая орфограмма в окончании слова - ученик определяет, что это слово относится к 1скл., подбирает существительное того же склонения, но с окончанием в сильной позиции и подставляет его на место проверяемого слова: на руке́ (1 скл.) $\rightarrow$ в окончании слова на тропинк... надо писать окончание -е.

Выработку навыков орфографической зоркости необходимо начинать со звуко-буквенного анализа слов. Самую значительную часть орфограмм русского 
языка составляют орфограммы слабых позиций, к которым в первую очередь относятся безударные гласные в разных частях слова, согласные парные по звонкости-глухости, стоящие на конце слов и перед другими согласными.

Орфографическая зоркость формируется постепенно в процессе выполнения разнообразных упражнений, является результатом многократных действий.

Я использую следующие виды упражнений для развития орфографической зоркости.

Письмо с проговариванием. Сначала проговариваю сама так, как надо писать 1-2 слова по слогам, затем хором так же (орфографически). Эту работу веду с 1 класса. Обучающийся, диктуя себе предложение, каждое слово произносит орфографически, четко, по слогам. Работа речевого аппарата и процесс проговаривания создает своеобразный запоминательный образ слова, многократное повторение в слух и про себя способствует более прочному запоминанию его написания.

Списывание (проговаривая по слогам). Этот вид списывания предполагает большую самостоятельность учащихся. Слово они слышат не от учителя, а находят его в книге и читают сами. В процессе списывания у детей развивается зрительная и слуховая память.

\section{АЛГОРИТМ СПИСЫВАНИЯ.}

1. Прочитай слово или предложение.

2. Повтори его, не заглядывая в текст.

3. Подчеркни в слове или предложении все орфограммы

4. Прочитай предложение орфографически.

5. Повтори предложение орфографически проговаривая все звуки.

6. Закрой текст. Начинай писать диктуя по слогам (орфографически) и подчеркни орфограммы.

7. Сверь написанное с текстом, особое внимание обрати на орфограммы [3].

Комментированное письмо. Обучающиеся обосновывают правописание правилами, подбором проверочных слов. Здесь очень важно, чтобы все работали 
с комментатором, не отставая и не забегая вперёд. Сначала прошу комментировать сильных учащихся, затем постепенно включаются и все остальные.

Письмо под диктовку с предварительной подготовкой. Сначала с учащимися разбираем правописание тех слов, которые требуют проверки. Затем дети пишут данное предложение или текст под диктовку.

Списывание, комментированное письмо, письмо по памяти, словарные диктанты, диктанты с элементами игры, диктанты с самопроверкой - развивают и формируют орфографическую зоркость.

Игры, используемые в работе: «Найди опасное место»: учитель произносит слово, учащиеся хлопают в ладоши, слыша звук, которому нельзя доверять. «Светофор»: Покажите красный сигнал «светофора», как только найдёте в слове «опасное место». «Кто больше насобирает орфограмм?», «От значения слова к правильной букве». Если формировать у детей привычку задумываться над значением слова, то это повышает их грамотность. Пример: храбрец от слова храбрый; кофейник от слова кофе.

Прием "Секрет письма зеленой пастой", с помощью которого дети оформляют письменные работы в тетрадях: как только появляется правило начинает работать зеленая паста. Чем больше орфограмм изучается, тем чаще зеленый свет "зажигается" в тетрадях учеников.

Использую приём - кластер «Гроздь». Работа с кластером «гроздью» проста и доступна. Пишу в центре слово, например,- мороз-, и от этого центра отходят лучи-орфограммы этого слова, его морфологические признаки. От каждого заголовка могут идти ответвления, формирующие гроздь. Прием «мозговая атака» способствует созданию большого количества «гроздей». Данный прием разнообразит деятельность обучающихся, побуждает их к лучшему запоминанию словарных слов, повышает интерес. (Рис.1) 


\section{Приём «Составление кластера»}

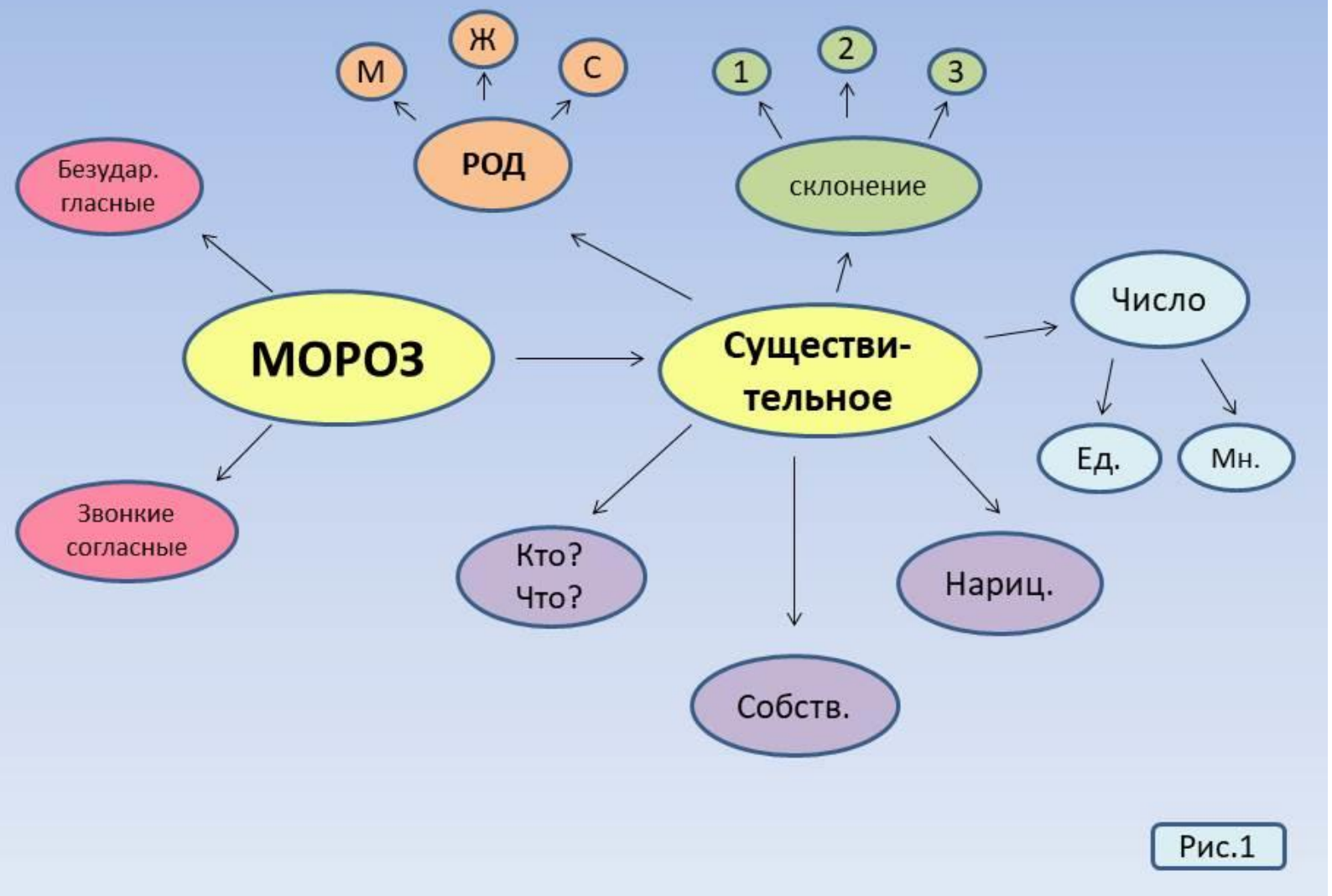

Рис.1 Приём - кластер «Гроздь»

Прием «Корзина идей». Групповая работа. Каждая группа подбирает трудные по написанию слова, затем идет запись и объяснение орфограмм. Прием «Найди ошибку». Заранее подбираю текст, содержащий ошибочную информацию, предлагаю найти допущенные ошибки. Использование таких заданий позволяет лучше запомнить изученные орфограммы, четче формулировать свои мысли, активизирует деятельность обучающихся на уроке.

Систематическая работа по предупреждению ошибок на каждом уроке дает неплохие результаты, оказывает положительное влияние на грамотное письмо, приводит к снижению орфографических ошибок. Очень важно вести эту работу в начальной школе, так как в последующем она продолжится в старших классах. При подготовке к ОГЭ есть такие задания, как орфографический анализ слова. Вариант данного задания ОГЭ приведен ниже на рисунке 2 [5]. 
5 Орфографический анализ.

Укажите варианты ответов, в которых дано верное объяснение написания выделенного слова. Запишите номера этих ответов.

1) ПРОДАВЕЦ - написание безударной гласной в корне слова проверяется подбором однокоренного слова, в котором эта гласная находится в ударном слоге.

2) ПОСТЕЛЕШЬ - в окончании глагола II спряжения в форме 2-го лица единственного числа пишется буква Е.

3) УСЛЫШАНА (песня) - в имени прилагательном, образованном от основы глагола с помощью суффикса -АН-, пишется одна буква Н.

4) НАСТЕЖЬ - в наречии, оканчивающемся на шипящий, пишется буква Ь.

5) НЕ СКАЗАВ - частица НЕ с кратким страдательным причастием прошедшего времени пишется раздельно.

Ответ:

Рис. 2 Задания из материалов ОГЭ

Если обучающиеся научатся видеть орфограммы, это окажет положительное влияние на грамотное письмо.

Я считаю данную работу актуальной во все времена. Она адаптирована в соответствии с современными требованиями.

\section{ЛИТЕРАТУРА}

1. Львов М.Р. Правописание в начальных классах. - М.:Просвещение,1998

2. Рождественский Н.С. Речевое развитие младших школьников.М.:Просвещение, 1980

3. Фролова Л.А. Структура орфографической зоркости и условия ее развития у младших школьников.//Начальная школа,2001 №5

4. Бочкарева Т.Д. Предупреждение ошибок.//Начальная школа,2001 №3

5. Цыбулько И.П. ОГЭ. Русский язык: типовые экзаменационные варианты. -М.: Национальное образование,2020.-240 с. 